\title{
Testing Keynesian Proposition And Ricardian Equivalence: More Evidence On The Debate
}

George A. Vamvoukas, Athens University of Economics, Greece Vassilios N. Gargalas, Herbert H. Lehman College

\begin{abstract}
This paper takes its motives from recent literature concerning the debate on the Keynesian proposition and the Ricardian equivalence, using data of the Greek economy and applying cointegration analysis, Granger causality tests and impulse response functions (IRF). The aim of the econometric methodology is to derive robust results by means of using alternative quantitative techniques. The empirical analysis shows the existence of dynamic relationships between the budget deficit and the interest rate, indicating a two-way causality between deficits and interest rates. The findings of Granger tests and IRFs contradict the view of Ricardian equivalence that government deficits do not influence the behavior of interest rate. Experimenting with the fourvariable system $(R, D, Y, P)$, IRF results show that in the case of Greece the budget deficit positively affects the inflation rate. The evidence that budget deficits exert positive effects on interest rates and inflation is consistent with the rationale of the Keynesian proposition.
\end{abstract}

Keywords: Budget deficit, Cointegration, Granger causality, Impulse response functions (IRF), Keynesian proposition, Ricardian equivalence

\section{INTRODUCTION}

O ince the mid 1970s there has been much empirical and theoretical work about the effects of government deficits on real economic activity. A considerable number of researchers have focused on testing the Keynesian proposition and the Ricardian equivalence ${ }^{1}$. According to the Keynesian proposition (the conventional view), the high budget deficits financed by issuing bonds increase the national debt and affect several macroeconomic variables such as real output, inflation, money supply, interest rates, current account, etc. Based on the logic of the Ricardian equivalence, the scenario of the Keynesian proposition is incorrect. The issue of the Ricardian equivalence states that the deficit does not matter, because an increase in government deficit is effectively equivalent to a future increase in tax liabilities. Considering that lower taxation in the present is offset by higher taxation in the future, it means that budget deficits do not influence the main macroeconomic variables.

Several empirical studies by Bovenberg (1988), Laumas (1989), Dua (1993), Knot and De Haan (1995), and Reinhart and Sack (2000), among others, have provided evidence in line with the rationale of the Keynesian proposition. On the other hand, other authors such as Barro (1974, 1987), Evans (1987), Darrat (1990), Beard and McMillin (1991), and Cheng (1998), support the Ricardian equivalence that government deficits have no impact on key macroeconomic variables. The basic purpose of this paper is to explore the interaction between government deficits and interest rates using data from the Greek economy. Most of the empirical studies have employed data from large developed countries and mainly from the United States. Thus, more research work must be conducted on the debate using data from various developed and developing countries.

This paper re-examines the causal links between government deficits and interest rates from a time series perspective employing modern econometric techniques. In particular: a) the paper exploits the integration properties of the data using appropriate strategies when the series are non-stationary; b) the paper examines the cointegration 
properties of the system variables; c) the two paradigms are investigated within the empirical framework of multivariate Granger causality using the valuable information from the error-correction mechanism; and d) the robustness of Granger tests is checked within the empirical context of impulse response functions.

The outline of this study is as follows: Section II reviews in brief the theoretical background of the Keynesian proposition and the Ricardian equivalence. Section III presents the data, analyses the econometric methodology and provides causality test results. Section IV examines the robustness of Granger causality tests. Finally, Section $\mathrm{V}$ gives the main concluding remarks.

\section{THEORETICAL ISSUES}

As known, the government deficit equals government expenditures minus government revenues. To finance the deficit, the government issues new debt, so that the deficit equals the amount of new debt. Budget deficits have been the subject of empirical work examining the relationship between deficits and other important macroeconomic variables like inflation and the rate of interest. To illustrate the Ricardian equivalence let us assume that government purchases remain constant and that the government decides a cut in taxes. The Ricardian equivalence states that lump-sum changes in tax revenues will not affect the level of total consumption, total savings, the rate of interest, money demand and other important macroeconomic variables.

Suppose that the government reduces taxes by $€ 100$. The tax cut should lead people to increase consumption, because the current tax cut increases their current incomes. However, given that the government has not changed its expenditures for goods and services, the $€ 100$ tax cut today must also increase current borrowing by $€ 100$. Because the additional debt of $€ 100$ will be repaid in the future, tax revenues will be higher in the future implying lower future disposable incomes for the people. The decline in future disposable incomes will cause people to consume less today, offsetting the positive effects on consumption of the $€ 100$ current tax cut. In this way, the total effect of a current tax cut on desired consumption is zero, because the positive effects of increased current disposable income and the negative effects of declined future disposable income cancel each other out.

Considering that government deficits do not influence total consumption and savings, the level of interest rate remains constant and the demand for money is not affected. Within the IS-LM model the rationale of the Ricardian theorem indicates that budget deficit increases do not affect the equilibrium point of the IS and LM curves. Thus, government deficits do not influence the equilibrium level of interest rate and other key macroeconomic variables such as consumption, savings, inflation, etc ${ }^{2}$.

In the framework of the Keynesian proposition, government deficit increases cause changes to the level of the main macroeconomic variables. Budget deficits resulting from an increase in government expenditures, tax cuts, or both, will cause a reduction in desired national savings, shifting the IS curve to the right and hence increasing aggregate demand. The result will be a rise in the price level causing the interest rate to increase. Thus, in the Keynesian model budget deficits will be correlated with inflation and interest rate increases.

The Keynesians also argue that higher interest rates and inflation are the result of the positive effects of budget deficits on money supply. As known, the central bank can finance the government deficit by printing money or selling bonds. The government may deliberately raise the supply for money in an effort to obtain revenues and thus to cover the deficits. An increase in money supply caused by financing deficits will tend to feed inflation and to raise interest rates. Since 1980 the United States and many European Union countries such as Greece have often experienced large government deficits. In the 2000s the deficits in the United States and the Eurozone appear to follow an increasing path. In this sense, the government deficit constitutes a key economic variable which seems to affect the behavior of the macroeconomy.

\section{DATA, COINTEGRATION, CAUSALITY}

The list of variables included in the empirical analysis is: the government deficit (D), one year bond rates $(\mathrm{R})$, the inflation rate $(\mathrm{P})$ and the real GNP at market prices (Y). The data are annual covering the period 1948 to 
2001 and are collected by the Ministry of National Economy and the National Statistical Service of Greece. Before 1948 insufficient data for all the variables are available, so that the estimation period is over the years 1948 to 2001. $\mathrm{D}$ is expressed in real terms and P is measured by CPI (Consumer Price Index). Note that in Greece the fiscal year starts on January 1 and ends on December 31.

The ulterior purpose of the methodology adopted in this paper is to explore the robustness of the empirical results to various generalizations of the estimated models. The links between $\mathrm{D}$ and $\mathrm{R}$ are investigated in the context of alternative causality tests. Granger-type causality tests are conducted using lag lengths determined by two model specification criteria. The robustness of the Granger-causality results is explored by applying impulse response functions (IRF), where the time series are jointly determined. In this way, IRFs provide an indication of the causal properties of the system variables $(\mathrm{D}, \mathrm{R}, \mathrm{Y})$ and $(\mathrm{D}, \mathrm{R}, \mathrm{Y}, \mathrm{P})$. The aim of implementing multivariate causality tests and IRFs is to avoid the possibility of specification bias. Using a model specification which is based on a simple two-variable relationship, it is possible for the causality tests to produce misleading results if important variables are omitted from the system. Therefore, if key variables are omitted from the Granger causality procedure, the tests may yield spurious and unreliable conclusions as to the Keynesian proposition and the Ricardian equivalence.

The first step in our empirical procedure is related to establishing the degree of integration of the time series. A precondition for cointegration is to examine the unit root features of each variable under study. The integration properties of each series are investigated by executing Augmented Dickey-Fuller (ADF), Phillips-Perron (PP) and Elliot-Rothenberg-Stock (ERS) unit-root tests. The ADF, PP and ERS equations include a constant and a time trend to permit for a deterministic trend under the alternative hypothesis. The results of unit-root tests are reported in Table 1. ADF, PP and ERS tests do not reject the null hypothesis of nonstationarity, indicating that the series D, R, Y, P have a unit root. Using first-differenced data all reported t-ratios suggest that the series are integrated of order one I(1).

Having investigated the stationarity properties of the series under study, the second step of the empirical procedure is to provide a formal analysis of the long-run co-movement in the four series. Cointegration tests are carried out employing the well-established technique of Johansen $(1988,1991,1995)$ which is based on the following equation:

$\Delta \mathrm{X}_{\mathrm{t}}=\Gamma_{1} \Delta \mathrm{X}_{\mathrm{t}-1}+\ldots+\Gamma_{\mathrm{k}-1} \Delta \mathrm{X}_{\mathrm{t}-\mathrm{k}+1}+\Pi \mathrm{X}_{\mathrm{t}-\mathrm{k}}+\mu+\mathrm{u}_{\mathrm{t}}$

where $\mathrm{X}_{\mathrm{t}}$ is a vector of variables; $\mu$ is a constant vector; $\Delta \equiv(1-\mathrm{L})$ is the first-difference operator; $\Pi$ is the coefficient matrix with reduced rank $r<\mathrm{k}$; and $\mathrm{u}_{\mathrm{t}}$ is a vector of innovations.

The null hypothesis that there are at most $r$ cointegrating vectors is tested employing the trace statistic, $\lambda_{\text {trace }}$, and the maximum eigenvalue statistic, $\lambda_{\max }$. The trace statistic is given as follows:

$$
\lambda_{\text {trace }}(r)=-T \Sigma \sum_{j=r+1}^{2} \ln \left(1-\lambda_{j}\right)
$$

The maximum eigenvalue statistic is calculated as:

$\lambda_{\max }(\mathrm{r}, \mathrm{r}+1)=-\mathrm{T} \ln \left(1-\lambda_{\mathrm{r}+1}\right)$

Table 2 presents the Johansen cointegration test results based on $\lambda_{\text {trace }}$ and $\lambda_{\text {max }}$. When the Johansen procedure is performed, the level data have linear deterministic trends and the cointegrating equations have intercepts. The AIC (Akaike Information Criterion) is used to define the lag length specification of the three- and four-variable system. The null hypothesis of at most one cointegrating relationship is not rejected in either system. The variables tend to move together in the long-run and, hence, share a long-run component and do not drift apart over time. 
According to the Granger-representation theorem, the existence of a long-run equilibrium relationship between a set of variables enables us to estimate at least one error-correction model (ECM). Given that the variables are cointegrated, their pattern of causality must be tested in the context of an ECM formulation. A main methodological contribution of ECM strategy is that the estimation procedure takes into account the short- and longrun dynamics of the system.

In this paper, a Granger testing approach is applied to investigate the direction of causality between D and $\mathrm{R}$ using the AIC and Theil's $\mathrm{R}^{2}$ (TC) to select lags. To specify the optimal lags, the AIC and TC criteria are calculated in a 3-step procedure. First, setting $\mathrm{k}=0$, I determine $\mathrm{m}=\mathrm{m}^{*}$ which minimizes $\operatorname{AIC}(\mathrm{m})$ and $\mathrm{TC}(\mathrm{m})$. Second, having selected $\mathrm{m}=\mathrm{m}^{*}$, I solve for $\mathrm{k}=\mathrm{k}^{*}$ so as to minimize $\mathrm{AIC}\left(\mathrm{m}^{*}, \mathrm{k}\right)$ and $\mathrm{TC}\left(\mathrm{m}^{*}, \mathrm{k}\right)$. Third, having chosen $\mathrm{k}=\mathrm{k}^{*}$, I select $\lambda=\lambda^{*}$ so as to minimize $\operatorname{AIC}\left(\mathrm{m}^{*}, \mathrm{k}^{*}, \lambda\right)$ and $\mathrm{TC}\left(\mathrm{m}^{*}, \mathrm{k}^{*}, \lambda\right)$. The resulting lag structure $\left(\mathrm{m}^{*}, \mathrm{k}^{*}, \lambda^{*}\right)$ determines the optimal lag lengths for the trivariate system $(\Delta \mathrm{D}, \Delta \mathrm{R}, \Delta \mathrm{Y})$. The same technique is followed within the four-variable system $(\Delta \mathrm{D}, \Delta \mathrm{R}, \Delta \mathrm{Y}, \Delta \mathrm{P})^{3}$.

Based on the above-described Granger causality technique, causality tests are reported in Table 3 . The error-correction terms $\mathrm{E}_{\mathrm{t}-1}$ and $\mathrm{C}_{\mathrm{t}-1}$ produced from the Johansen procedure are the cointegrating vectors included in the group of regressors. The coefficients $\delta_{1}$ and $\delta_{2}$ provide evidence of the long-run dynamics between $\Delta \mathrm{D}$ and $\Delta \mathrm{R}$. The essential conclusion is that, in the case of Greece, the empirical evidence is consistent with the Keynesian proposition. Granger causality tests seem robust, showing an obvious bi-directional causality between $\Delta \mathrm{D}$ and $\Delta \mathrm{R}$. The values of $\mathrm{E}_{\mathrm{t}-1}$ and $\mathrm{C}_{\mathrm{t}-1}$ indicate long-run causal consequences between government deficits and interest rates. The BG tests suggest that serial correlation is not a problem in the sample data. The fact that government deficits cause positive interest rate changes reflects the validity of the Keynesian proposition.

\section{ROBUSTNESS CHECKS}

The results of Table 3 suggest that in the case of Greece government deficits are an important causal determinant of interest rates. This section examines the robustness of Granger causality tests in the empirical framework of impulse response functions (IRF). The impulse response function traces the predictable response of each endogenous variable over time to a shock in that variable and in every other endogenous variable of the system. IRFs can give an indication of the pattern of causality between D and R. By performing IRFs a researcher can investigate the channels through which $\mathrm{D}$ and $\mathrm{R}$ operate without assuming any constraint on other system variables. The purpose of IRF methodology is to consider all the variables as jointly determined and to face the case of specification bias. The empirical procedure in this paper is based on Amisano and Giannini (1998).

Consider the $Z_{t}$ vector of the endogenous variables where $t=1, \ldots, k$ and let $\Phi=H\left(e_{t} e_{t}^{\prime}\right)$ be the residual covariance matrix. In the methodological context of Amisano and Giannini (1998), the following structural VAR(SVAR) model has to be estimated:

$\mathrm{Ee}_{\mathrm{t}}=\mathrm{Fu}_{\mathrm{t}}$

where $\mathrm{E}$ and $\mathrm{F}$ are $\mathrm{k} \times \mathrm{k}$ matrices to be estimated; $\mathrm{e}_{\mathrm{t}}$ is the reduced form disturbance terms; and $\mathrm{u}_{\mathrm{t}}$ is the unobserved structural innovations. Innovations are assumed to be orthonormal and thus $\mathrm{H}\left(\mathrm{e}_{\mathrm{t}} \mathrm{e}_{\mathrm{t}}^{\prime}\right)=\mathrm{I}$ e.g. the residual covariance matrix is an identity matrix. Given that $\mathrm{u}_{\mathrm{t}}$ are orthonormal innovations, the following identifying restrictions on $\mathrm{E}$ and $\mathrm{F}$ matrices are imposed:

$\mathrm{E} \Phi \mathrm{E}^{\prime}=\mathrm{FF}^{\prime}$

where both sides of 5 are symmetric. In Figures 1 and 2, IRF results are derived by estimating the orthogonal factorization matrices $\mathrm{E}$ and $\mathrm{F}$.

Figures 1 and 2 show IRFs for the three- and four-variable model (R, D, Y) and (R, D, Y, P). Considering that both models are cointegrated, in the estimation procedure the variables are used in levels. In all cases, IRFs are to a ten-basis-point shock to D and R. The residuals are orthogonalized by the Choleski decomposition. Standard 
errors were computed using Monte Carlo methods with one hundred draws from the estimated distributions of the SVAR parameters. Impulse responses are plotted along with their respective two-standard-deviation confidence bounds.

The results indicate the existence of dynamic causal effects between D and R. In Figure 1 the first row of the second column indicates that the responses of the rate of interest to government deficit disturbances are positive in all horizons. The positive responses appear to be strong and persistent. The evidence that innovations to D evoked positive and significant consequences in $\mathrm{R}$ is in line with the theoretical grounds of the Keynesian view. Figure 2 shows that the second row of first column the positive response of government deficit to shocks in the interest rate is positive across all horizons. Note that shocks to $\mathrm{D}$ cause positive movements to $\mathrm{P}$, showing that $\mathrm{D}$ is a key variable in the four-variable system (R, D, Y, P). The evidence in Figures 1 and 2 does not cast any doubts on the key role of $\mathrm{D}$, leading us to reject the theoretical background of the Ricardian equivalence ${ }^{4}$. The empirical findings in Figures 1 and 2 are consistent with those of Table 3.

\section{SUMMARY AND CONCLUSIONS}

Since 1974 there has been a growing interest in the field of applied economics in testing the relationship between government deficits and other important macroeconomic variables such as the interest rate, inflation, money supply, current account, private consumption, etc. Most of the recent research in this area has focused on the acceptability and validity of the Keynesian proposition (conventional view) and the Ricardian equivalence hypothesis. However, except for a considerable number of studies based on data of the U.S. economy, in other developing countries not much empirical work has been done on the links among budget deficits, the rate of interest and inflation.

Based on annual data of the Greek economy between 1948 and 2001, performing Granger causality tests within the framework of ECM modelling and employing IRFs, the objective of this paper is to test empirically the acceptance of the Keynesian proposition and the Ricardian equivalence. ADF, PP and ERS unit-root tests are used to check the time series D, R, Y and P for stationarity. The hypothesis of nonstationarity is tested including a constant and a time trend in the estimation procedure. Unit-root tests suggest that the null is soundly rejected by the first differenced data. Thus, D, R, Y and P are assumed to be difference-stationary. Having established that each series is $\mathrm{I}(1)$, the Johansen cointegration approach is applied to explore the cointegration of variables in $(D, R, Y)$ and $(D, R$, Y, P) systems. The empirical results show that the $\lambda_{\text {trace }}$ and $\lambda_{\max }$ statistics fail to reject the null of no cointegration among the system variables.

Cointegration is a necessary and sufficient condition for the formulation of the variables in an ECM. In the ECM representation short-run dynamics are captured by the first differences of the variables and long-run dynamics are considered through the error-correction terms $\mathrm{E}_{\mathrm{t}-1}$ and $\mathrm{C}_{\mathrm{t}-1}$. The pattern of causality between $\mathrm{D}$ and $\mathrm{R}$ is investigated within the empirical framework of ECM strategy. Granger tests reveal both-way causality between D and R. The message that a change in government deficit implies a positive effect on the rate of interest supports the theoretical grounds of the Keynesian proposition. The estimated IRFs, shown in Figures 1 and 2, seek the robustness of the Granger tests of Table 3. The IRF results suggest that $D$ is a leading variable causing a positive impact on $R$ and $\mathrm{P}$.

Overall, the empirics are in accord with the logic of the Keynesian proposition. In Greece, over the time frame 1948-2001 debt monetization was a basic target of fiscal and monetary policies. An argument for debt monetization is that the government sells bonds to finance a deficit. The debt issued to finance the government deficit is to some extent monetized, because bonds are a part of money supply. In Greece, between 1948 and 2001 government bonds and treasury bills were components of the $\mathrm{M}_{3}$ broad monetary aggregate. Fiscal authorities were dominant in the sense that they independently set the amount of revenue from bond sales to cover the gap of the deficits. Monetary authorities had no alternative but to finance the government deficits. Thus, over the time period 1948-2001, the interest rate and the monetary base could not be manipulated independently of fiscal policy, so that monetary authorities were the follower and fiscal authorities were the leader ${ }^{5}$. It seems that policy makers, trying to control budget deficits, considered these monetary aggregates as the chief intermediate monetary policy targets. 


\section{NOTES}

1. Bernheim (1989), Seater (1993) and Vamvoukas (1997) provide a detailed discussion on both the Keynesian and Ricardian equivalence paradigms.

2. The argument raised by the Ricardian equivalence is that government bonds are not net wealth. According to Barro $(1974,1987)$ and other advocates of the Ricardian equivalence, public debt financing by bond issue postpones taxation imposition for the future. Consequently, future taxation is equivalent to current taxation and therefore people realize that their government bonds will be paid off with increases in future taxes.

3. Note that experimenting with lags from 1 to 6 and by running more than 100 regressions, I selected the lag that produced the smallest AIC and the highest $\mathrm{R}^{2}$ for TC.

4. It is interesting that when the series $\mathrm{D}$ is placed first or last in both orderings, the effects of $\mathrm{D}$ on $\mathrm{R}$ and $\mathrm{P}$ appear to be significantly large from an economic point of view. Details of these IRF results are available from the author upon request.

5. Empirical evidence provided by Vamvoukas (1998) shows that in the case of Greece budget deficits affect positively the behavior of money supply. Taking into account that government deficits exert positive effects on money supply, it is obvious that increases in money supply encourage the price level to rise.

\section{REFERENCES}

1. Amisano, G. and Giannini, C. (1998), Topics in Structural VAR Econometrics, Springer-Verlag, Berlin.

2. Barro, R. (1974), Are Government Bonds Net Wealth? Journal of Political Economy, 82, 6, Nov./Dec., pp.1097-117.

3. Barro, R. (1987), Government Spending, Interest Rates, Prices, and Budget Deficits in the United Kingdom, 1701-1918, Journal of Monetary Economics, 20, No. 2, Sept., pp.221-47.

4. Beard, T.R. and McMillin, W.D. (1994), The Impact of Budget Deficits in the Interwar Period, Journal of Macroeconomics, 13, No. 2, Spring, pp.239-66.

5. Bernheim, B. (1989), A Neoclassical Perspective on Budget Deficits, Journal of Economic Perspectives, 3, No. 2, Spring, pp.55-72.

6. Bovenberg, L.A. (1988), Long-Term Interest Rates in the United States: An Empirical Analysis, IMF Staff Papers, 35, No. 2, June, pp.382-90.

7. Cheng, B.S. (1998), The Causality between Budget Deficits and Interest Rates in Japan: An Application of Time Series Analysis, Applied Economics Letters, 5, No. 7, July, pp.419-22.

8. Darrat, A.F. (1990), Structural Federal Deficits and Interest Rates: Some Causality and Cointegration Tests, Southern Economic Journal, 56, No. 3, January, pp.752-59.

9. Dua, P. (1993), Interest Rates, Government Purchases, and Budget Deficits: A Forward-Looking Model, Public Finance Quarterly, 21, No. 4, Oct., pp.470-78.

10. Elliot, G., Rothenberg, T.J. and Stock, J.H. (1996), Efficient Tests for an Autoregressive Unit Root, Econometrica, 64, No. 4, July, pp.813-36.

11. Evans, P. (1987), Do Budget Deficits Raise Nominal Interest Rates?, Journal of Monetary Economics, 20, No. 2, Sept., pp.281-300.

12. Johansen, S. (1988), Statistical Analysis of Cointegration Vectors, Journal of Economic Dynamics and Control, 12, No. 2/3, June/Sept., pp.231-54.

13. Johansen, S. (1991), Estimation and Hypothesis Testing of Cointegration Vectors in Gaussian Vector Autoregressive Models, Econometrica, 59, No. 6, Nov., pp.1551-80.

14. Johansen, S. (1995), Likelihood-based Inference in Cointegrated Vector Autoregressive Models, Oxford University Press, Oxford.

15. Knot, D. and De Haan, J. (1995), Fiscal Policy and Interest Rates in the European Community, European Journal of Political Economy, 11, No. 1, March, pp.171-87.

16. Laumas, G.S. (1989), Anticipated Federal Budget Deficits, Monetary Policy and the Rate of Interest, Southern Economic Journal, 56, No. 2, Oct., pp.375-82.

17. MacKinnon, J.G. (1996), Numerical Distribution Functions for Unit Root and Cointegration Tests, Journal of Applied Econometrics, 11, No. 6, Nov./Dec., pp.601-18. 
18. Osterwald-Lenum, M. (1992), A Note with Quantiles of the Asymptotic Distribution of the Maximum Likelihood Cointegration Rank Tests Statistics, Oxford Bulletin of Economics and Statistics, 54, No. 3, Aug., pp.461-72.

19. Reinhart, V. and Sack, B. (2000), The Economic Consequences of Disappearing Government Debt, Brookings Papers on Economic Activity, 2, pp.163-220.

20. Seater, J. (1993), Ricardian Equivalence, Journal of Economic Literature, 31, No. 1, March, pp.142-90.

21. Vamvoukas, G.A. (1997), A Note on Budget Deficits and Interest Rates: Evidence from a Small Open Economy, Southern Economic Journal, 63, No. 3, January, pp.803-11.

22. Vamvoukas, G.A. (1998), The Relationship between Budget Deficits and Money Demand: Evidence from a Small Economy, Applied Economics, 30, No. 3, March, pp.375-82.

Table 1: Unit Root Tests, 1948-2001

\begin{tabular}{c|ccc}
\hline Variable & ADF & PP & ERS \\
\hline $\mathrm{D}_{\mathrm{t}}$ & -1.772 & -1.823 & -1.438 \\
$\mathrm{R}_{\mathrm{t}}$ & -0.439 & 0.240 & -1.079 \\
$\mathrm{Y}_{\mathrm{t}}$ & -1.909 & -1.590 & -1.699 \\
$\mathrm{P}_{\mathrm{t}}$ & -1.847 & -1.937 & -1.835 \\
$\Delta \mathrm{D}_{\mathrm{t}}$ & $-4.470^{*}$ & $-7.540^{*}$ & $-4.348^{*}$ \\
$\Delta \mathrm{R}_{\mathrm{t}}$ & $-3.210^{* * *}$ & $-4.168^{*}$ & $-3.273^{* *}$ \\
$\Delta \mathrm{Y}_{\mathrm{t}}$ & $-3.537^{* *}$ & $-4.978^{*}$ & $-3.615^{* *}$ \\
$\Delta \mathrm{P}_{\mathrm{t}}$ & $-5.659^{*}$ & $-8.154^{*}$ & $-5.528^{*}$ \\
\hline
\end{tabular}

*indicates significance at the $1 \%$ level

** indicates significance at the $5 \%$ level

*** indicates significance at the $10 \%$ level

Notes: For ADF and PP tests MacKinnon's (1996) t-values are used.

The reported values for ERS t-tests are taken from ERS tables (1996).

All the regressions are performed collecting one year lag length.

Table 2: Johansen Cointegration Tests, 1948-2001

\begin{tabular}{|c|c|c|}
\hline Null Hypothesis $\left(\mathrm{H}_{0}\right)$ & $\lambda_{\text {trace }}$ & $\lambda_{\max }$ \\
\hline \multicolumn{3}{|l|}{ I. Three-variable system $(\mathrm{D}, \mathrm{R}, \mathrm{Y})$} \\
\hline $\mathrm{r}=0$ & $47.2 *$ & $32.2 *$ \\
\hline $\mathrm{r}=1$ & 15.0 & 14.1 \\
\hline $\mathrm{r}=2$ & 0.3 & 0.3 \\
\hline \multicolumn{3}{|l|}{ II. Four-variable system (D,R,Y,P) } \\
\hline $\mathrm{r}=0$ & $63.1 *$ & $28.5^{*}$ \\
\hline $\mathrm{r}=1$ & 28.4 & 20.5 \\
\hline $\mathrm{r}=2$ & 12.5 & 13.1 \\
\hline $\mathrm{r}=3$ & 1.6 & 1.6 \\
\hline
\end{tabular}

* indicates significance at the 5\% level

Notes: The critical values from Osterwald-Lenum (1992) are used to evaluate the significance of $\lambda_{\text {trace }}$ and $\lambda_{\max }$ statistics. The lags of the test VAR are selected using the AIC. The lag lengths of the three-variable system $(\mathrm{D}, \mathrm{R}, \mathrm{Y})$ and of the four-variable system $(\mathrm{D}, \mathrm{R}, \mathrm{Y}, \mathrm{P})$ were specified to be one and two years respectively. 
Table 3: Granger Causality Tests, 1948-2001

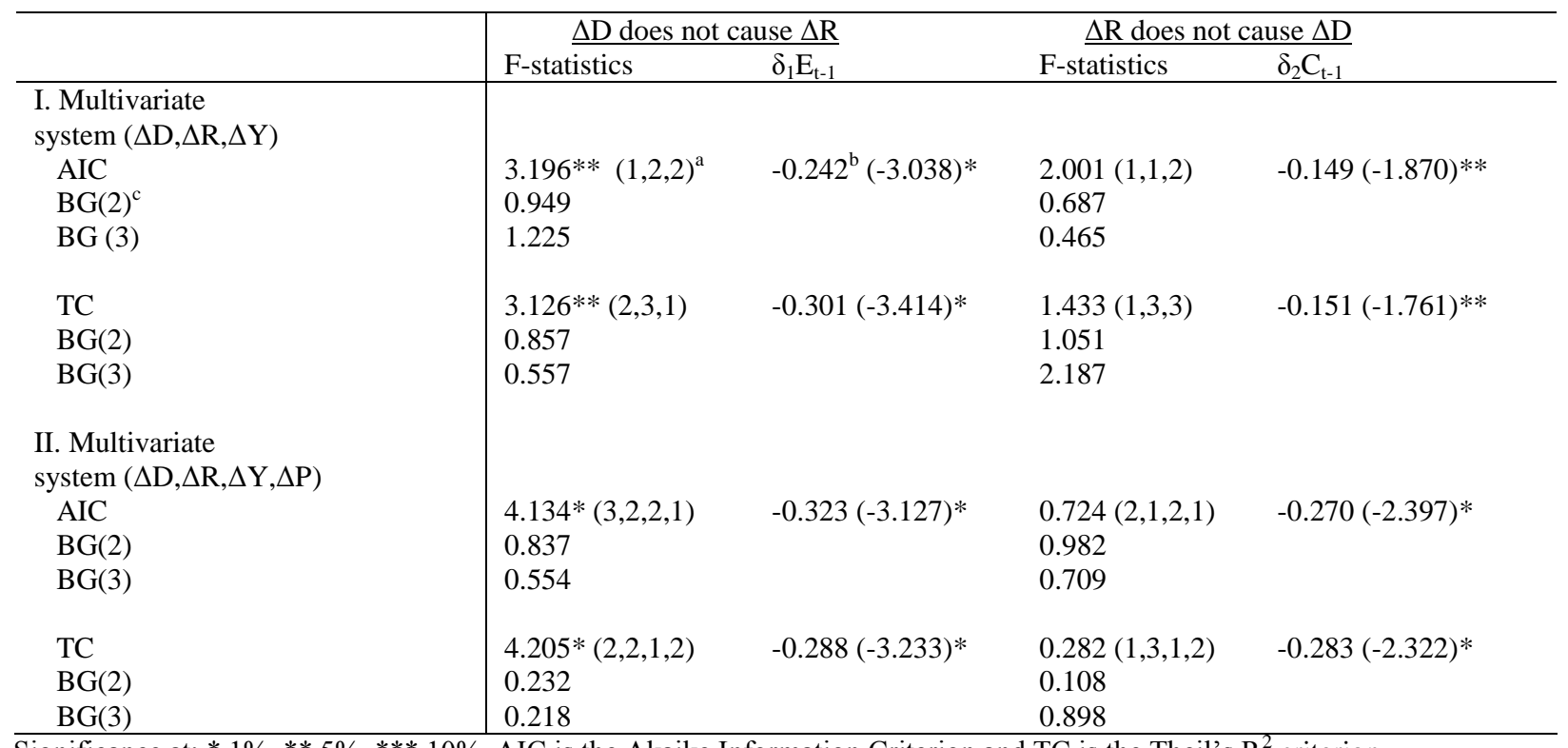

Significance at: $* 1 \%, * * 5 \%, * * * 10 \%$. AIC is the Akaike Information Criterion and TC is the Theil's $\mathrm{R}^{2}$ criterion.

a. Wald F-tests are performed to ascertain the joint significance of the lagged values of the independent variable. The numbers in parentheses show the lag order of $\Delta \mathrm{D}, \Delta \mathrm{R}$ and the control variables, respectively.

$\mathrm{b}$. The error-correction terms $\mathrm{E}_{\mathrm{t}-1}$ and $\mathrm{C}_{\mathrm{t}-1}$, lagged one period, are the cointegrating vectors saved from the Johansen cointegration tests. Asymptotic t-statistics in parentheses.

c. BG is the Breusch-Godfrey F-statistics for residual serial correlation. Number in parentheses is the lag length. 
Innovation to

$\propto$
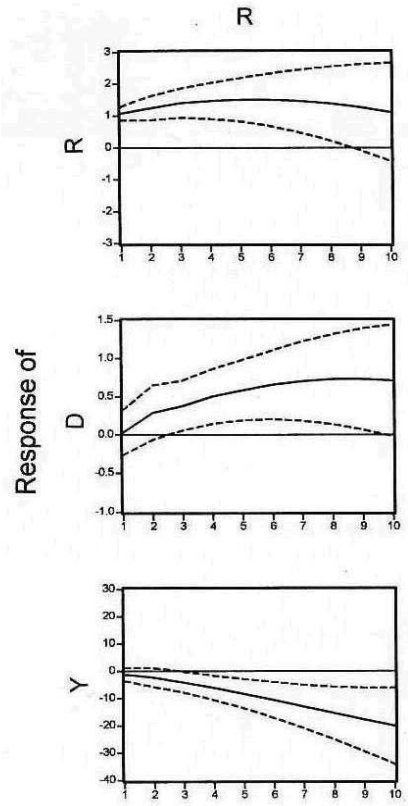

D
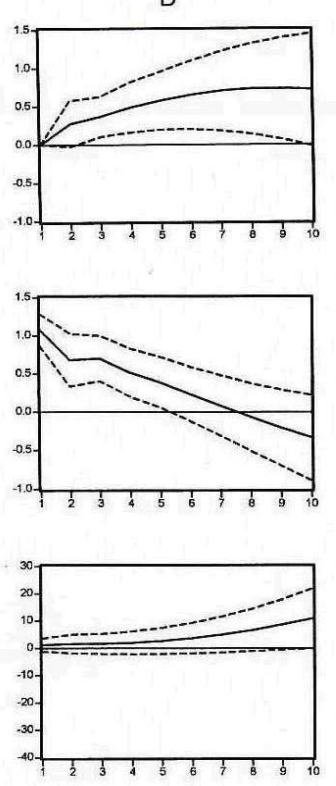

Y
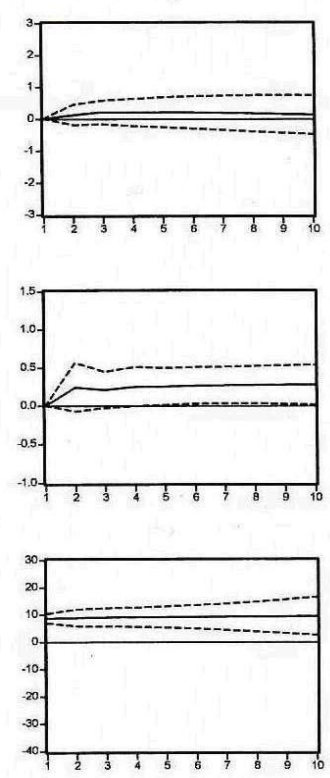

Figure 1. Impulse response functions for the system (R, D, $Y$ ) at a ten-year horizon between $1948-2001$.
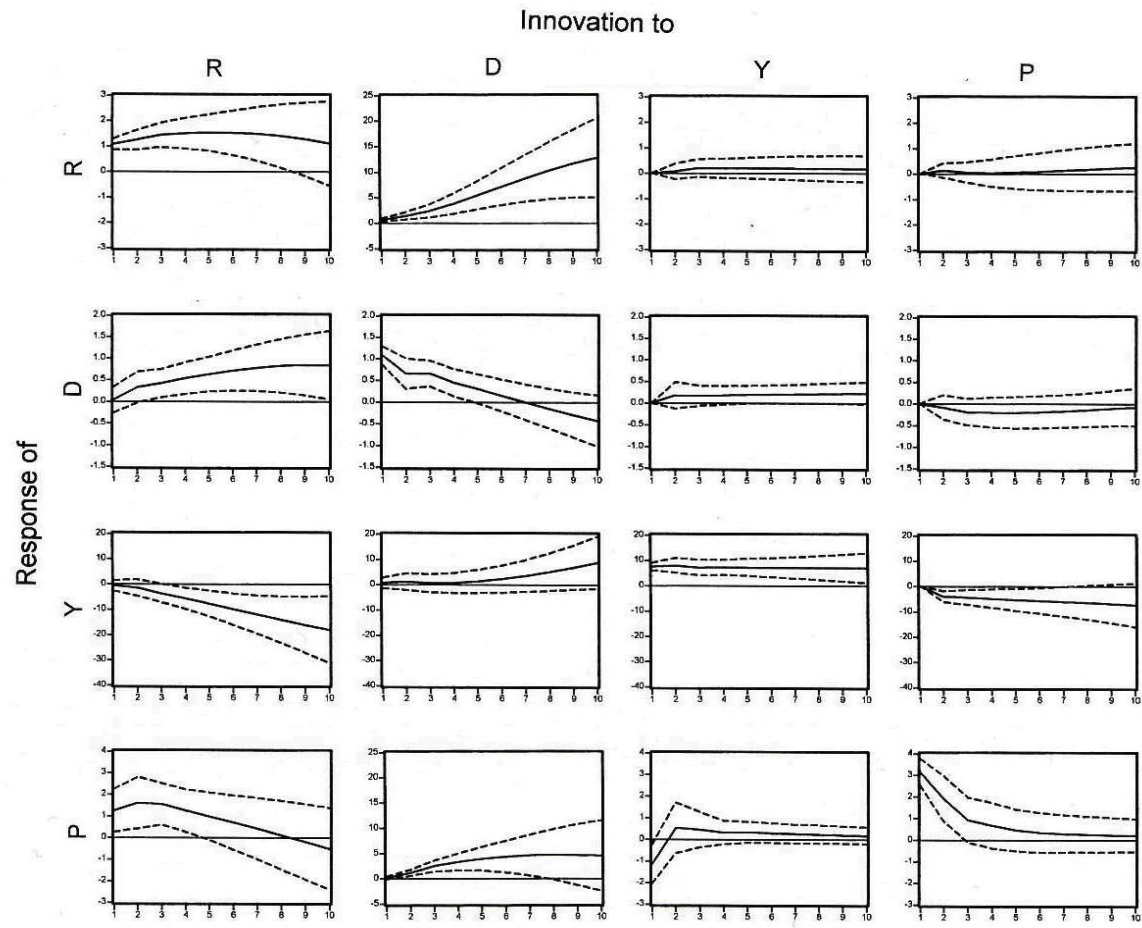

Figure 2. Impulse response functions for the system $(R, D, Y, P)$ at a ten-year horizon between $1948-2001$. 
NOTES 